\title{
DEBATING EDUCATION AND POLITICAL REFORM: THE FREINET MOVEMENT AND DEMOCRATISATION IN SPAIN (1975-1982)
}

DOI: http://dx.doi.org/10.1590/2236-3459/61932

\author{
José Luis Hernández Huerta
} University of Valladolid, Spain.

\author{
Alba María Gómez Sánchez \\ University of Salamanca, Spain.
}

\begin{abstract}
In the mid-1960s, the Freinet movement took on new life - first with the name Association for Correspondence and the School Printing Press - Acies -, and later as the Popular School Cooperative Movement - MCEP. In a short space of time, the organisation grew to contain over a hundred members and supporters, who, along with the process of the Transition to democracy, laid the foundations for many of Acies/MCEP's projects - both pedagogical and political projects. Of greatest importance amongst these were conferences, teacher-training seminars and the bulletin Colaboración (1976-1985), which was the organ of expression and communication for Spanish teachers following Freinet's principles. During the period of political transition to democracy, Acies/MCEP was one of the most active and dynamic Educational Renewal Movements in Spain. The present article explores the contributions of the Freinet movement to the democratisation of education in Spain - in particular, the political-pedagogical discussion on the principles and purposes of public education, how to understand it, the problems posed by the existence of privately-subsidised education, and the role of the school as a tool for community development and an arena for civic participation. For these reasons, as a documentary source to be explored in depth, the bulletin Colaboración has been chosen; it offers an example of the pedagogical press for teachers in the Spain of 1970s and 1980s, as it helped shape the educational mindset in place during this period and in the following years.

Key-words: Freinet, Spain, pedagogical press, educational renewal, transition to democracy, Colaboración.
\end{abstract}




\section{DEBATES SOBRE EDUCAÇÃO E REFORMA POLÍTICA: O MOVIMENTO FREINET E A DEMOCRATIZAÇÃO NA ESPANHA (1975-1982)}

Resumo

Em meados dos anos 1960, ressurgiu na Espanha o movimento Freinet, primeiro sob o nome de Asociación para la Correspondencia y la Imprenta Escolar - Acies - e, em seguida, passou a ser denominado Movimiento Cooperativo de Escuela Popular MCEP. Em pouco tempo, a organização contava com mais de uma centena de membros e seguidores, que, juntamente com o processo de transição à democracia, possibilitou que se empreendessem vários projetos, evidenciando um duplo caráter, pedagógico e político, das atividades da Acies/MCEP, entre os quais se destacaram os congressos, jornadas e seminários de formação e aperfeiçoamento profissional, assim como o boletim Colaboración (1976-1985), que foi o órgão de expressão e comunicação dos professores freinetianos espanhóis. Durante o período analisado, a Acies/MCEP se configurou como um dos movimentos de Renovação Pedagógica da Espanha mais ativos e dinâmicos. Este artigo indaga quais as contribuições do movimento freinetiano espanhol para a democratização do ensino durante o período mencionado, particularmente os debates políticos-pedagógicos sobre os princípios e fins da educação pública, a forma de compreendê-la, os problemas que envolviam a existência de uma educação privada subsidiada e o papel da escola como agente de desenvolvimento comunitário e cenário de participação cívica. Para tanto, utilizamos a coleção do boletim Colaboración como principal fonte documental, um exemplo representativo da imprensa pedagógica espanhola dos anos 70 e 80 do século 20, que contribuiu para a configuração do imaginário pedagógico vigentes nessas décadas e posteriores.

Palavras-chave: Freinet, Espanha, imprensa pedagógica, renovação pedagógica, transição democrática, Colaboración.

\section{DEBATES SOBRE EDUCACIÓN Y REFORMA POLÍTICA: EL MOVIMIENTO FREINET Y LA DEMOCRATIZACIÓN EN ESPAÑA (1975-1982)}

\section{Resumen}

A mediados de la década de 1960, resurgió en España el movimiento Freinet, primero bajo el nombre de Asociación para la Correspondencia y la Imprenta Escolar - Acies - y, luego, bajo el de Movimiento Cooperativo de Escuela Popular - MCEP. En poco tiempo, la organización contó con más de un centenar de socios y seguidores, lo cual, unido al proceso de transición a la democracia, posibilitó que se emprendieran varios proyectos que evidenciaron el doble carácter, pedagógico y político, de la actividad de Acies/MCEP, entre los cuales destacaron los congresos, jornadas y seminarios de formación y perfeccionamiento profesional y el boletín Colaboración (1976-1985), que fue el órgano de expresión y comunicación de los maestros freinetianos españoles. Durante el periodo de transición política a la democracia, Acies/MCEP se configuró como uno de los Movimientos de Renovación Pedagógica de España más activos y dinámicos. En este artículo se indaga en las contribuciones del movimiento freinetiano español a la democratización de la educación durante el mencionado periodo de tiempo, particularmente a los debates políticos-pedagógicos sobre los principios y los fines de la enseñanza pública, la forma de entenderla, los problemas que entrañaba la existencia de la enseñanza privada-concertada y el papel de la escuela como agente de desarrollo comunitario y escenario de participación cívica. Para lo cual se ha tomado como fuente documental básica la colección del boletín Colaboración, un ejemplo representativo de la prensa pedagógica profesional de la España de los años 70 y 80 del siglo 20, que contribuyó a configurar el imaginario pedagógico vigente en esas décadas y posteriores.

Palabras-clave: Freinet, España, prensa pedagógica, renovación pedagógica, transición democrática, Colaboración. 


\section{DÉBATS SUR L'ÉDUCATIO ET LA RÉFORME DES POLITIQUES: MOUVEMENT FREINET ET LA DÉMOCRATISATION EN ESPAGNE (1975-1982)}

\section{Résumé}

Au milieu des années 1960, il refait surface en Espagne le mouvement Freinet, d'abord sous le nom de Asociación para la Correspondencia y la Imprenta Escolar - Acies - puis a été rebaptisé Movimiento Cooperativo de Escuela Popular - MCEP. Bientôt, l'organisation a eu plus d'une centaine de membres et partisans, qui, avec le processus de transition vers la démocratie, a permis d'entreprendre divers projets, montrant activités avec caractère dual, éducatives et politiques de I'Acies/MCEP, parmi lesquels se trouvait sur les congrès, conférences et séminaires de formation et de perfectionnement professionnel, ainsi que le bulletin Colaboración (1976-1985), qui était l'expression de l'autorité et de la communication de enseignants freinetianos espagnols. Au cours de la période considérée, I'Acies/MCEP est configuré comme un des mouvements renouveau pédagogique en Espagne plus actives et dynamiques. Cette article demande quelles sont les contributions du mouvement freinetiano espagnol pour la démocratisation de l'éducation au cours de cette période, en particulier les débats politiques et pédagogiques sur les principes et objectifs de l'éducation public, comment le comprendre, les problèmes impliquant l'existence d'un l'enseignement privé subventionné et le rôle de l'école comme agent de développement de la communauté et le scénario de la participation civique. Par conséquent, nous utilisons la collection du bulletin Colaboración come source documentaire principal, un exemple représentatif de la presse éducatif espagnol des années 70 et 80 du 20ème siècle, qui a contribué à la configuration de la force imaginaire pédagogique de ces décennies et plus tard.

Mots-clé: Freinet, Espagne, la presse pédagogique, le renouveau pédagogique, la transition démocratique, Colaboración. 


\section{Introduction}

The Spanish Civil War (1936-1939) and the dictatorship led by Francisco Franco (1939-1975) tore apart and neutralised the initiatives for pedagogical renewal and modernisation which had developed in Spain during the late $19^{\text {th }}$ and early $20^{\text {th }}$ Centuries - particularly during the Second Republic (1931-1936). The most progressive school culture and vanguardist pedagogical ideology which survived had to do so in secret, or had to suffer a certain degree of metamorphosis of their most fundamental tenets in order to adapt to the guiding educational principles of National Catholicism - particularly during the first few decades of the Franco regime.

In the mid-1960s, pedagogical renewal began to live again, with the protagonists organising to form various Movements for Pedagogical Renewal (MRP/MPR), ultimately becoming one of the key factors in the modernisation and democratisation of education during the transition to democracy (1975-1982). Such movements, which connected with the utopian pedagogical ideals in force during the republican period, had the fundamental goal of revitalising and revivifying Spain's schooling system and developing pedagogical, social and political thought as a key point, with the aim of changing the world through education and culture (Groves, 2013a).

During these decades, Spain witnessed the resurgence of the Freinet movement - first under the auspices of the Association for Correspondence and the School Printing Press Acies -, and later the Popular School Cooperative Movement - MCEP -, which was one of the most active and dynamic factions. Thus, in a short space of time, the organisation grew to include over 100 members and supporters, which facilitated the launch of numerous important projects. Particularly noteworthy among these projects were the activities of self-training and technico-professional development, and the journal Colaboración (1976-1985), which was the official mouthpiece for Freinet's disciples in Spain.

This article investigates the contributions made by Spain's Freinet movement to the debates on the democratisation of education during the aforementioned period of time, with a focus on the conferences, self-training and professional-development days and seminars and, in particular, the contributions of Acies/MCEP, through Colaboración, to the politicopedagogical debates concerning the principles and aims of public education, how it should be understood, the problems posed by the existence of privately-funded education and the role of the school as a force for community development and an arena for civic participation. With these objectives in mind, the entire catalogue of Colaboración has been used as a fundamental documentary source. The collection comprises a total of 53 editions, in which were published some 700 texts, including editorials, opinion pieces, workshops, monographs, documents and reports, interviews, news and correspondence, with contributions being made by over 320 teachers in 21 different provinces. The collection is available for consultation in a number of public libraries in Spain, but the version used as a source for this study was provided directly by MCEP.

Hence, this research fits into a twofold broader frame of reference. Firstly, it is part of the study of MRPs during the latter days of Francoism and Spain's transition to democracy a topic to which scant attention has been paid by historiographers, in spite of its obvious 
importance in the modernisation and democratisation of education, both in terms of the legaladministrative side and of the culture at school (Groves, 2011a). Secondly, it forms part of the field of investigation of the pedagogical press and the educational historical heritage in modern Spain: Colaboración was a representative example of the professional pedagogical press in Spain in the 1970s and 1980s, which was well received by teachers and helped to sculpt the pedagogical outlook which prevailed in Spain during these and subsequent decades (Hernández Díaz, 2015; Hernández Díaz \& Hernández Huerta, 2013). Yet this rich source for analysis has been practically ignored by educational historians; to date, the author is not aware of any publication that systematically, methodically analyses the content of Colaboración.

Indeed, the possibilities offered by this documentation go beyond the limits of this article. By examining the journal, one might, amongst other things, gain a clear picture of the idea of education held and promulgated by Freinetian teachers in Spain; establish the focal points of those teachers' politico-pedagogical interests; reconstruct part of the movement's internal history; discover part of the life and activity of Acies/MCEP; develop a profile of its members; or gain an idea of the scholarly culture reigning in those schools where Freinet's "Modern School" techniques were employed. However, it must also be acknowledged that there are certain limitations to this source: two in particular merit attention. Firstly, it is important not to overestimate the publication's impact, or to try to extend the politico-pedagogical views of Freinet's followers to the rest of the MRPs with which they coexisted and collaborated. Secondly, the potential historiographical study of Colaboración needs to be enriched by other studies, such as those carried out by Tamar Groves in recent years (Groves, 2009, 2014b), which help to gain a more accurate and nuanced view of its content, to pinpoint the movement within a rich and diverse context, and to interpret the thoughts about school culture in a broader frame of reference - that of Acies/MCEP and also that of other MRPs. 
Figure 1 -

Colaboración. Acies' newsletter, n. 1, sep./oct. 1976, and Colaboración, Newsletter of the Movimiento Cooperativo de Escuela Popular, n. 6, july 1977.

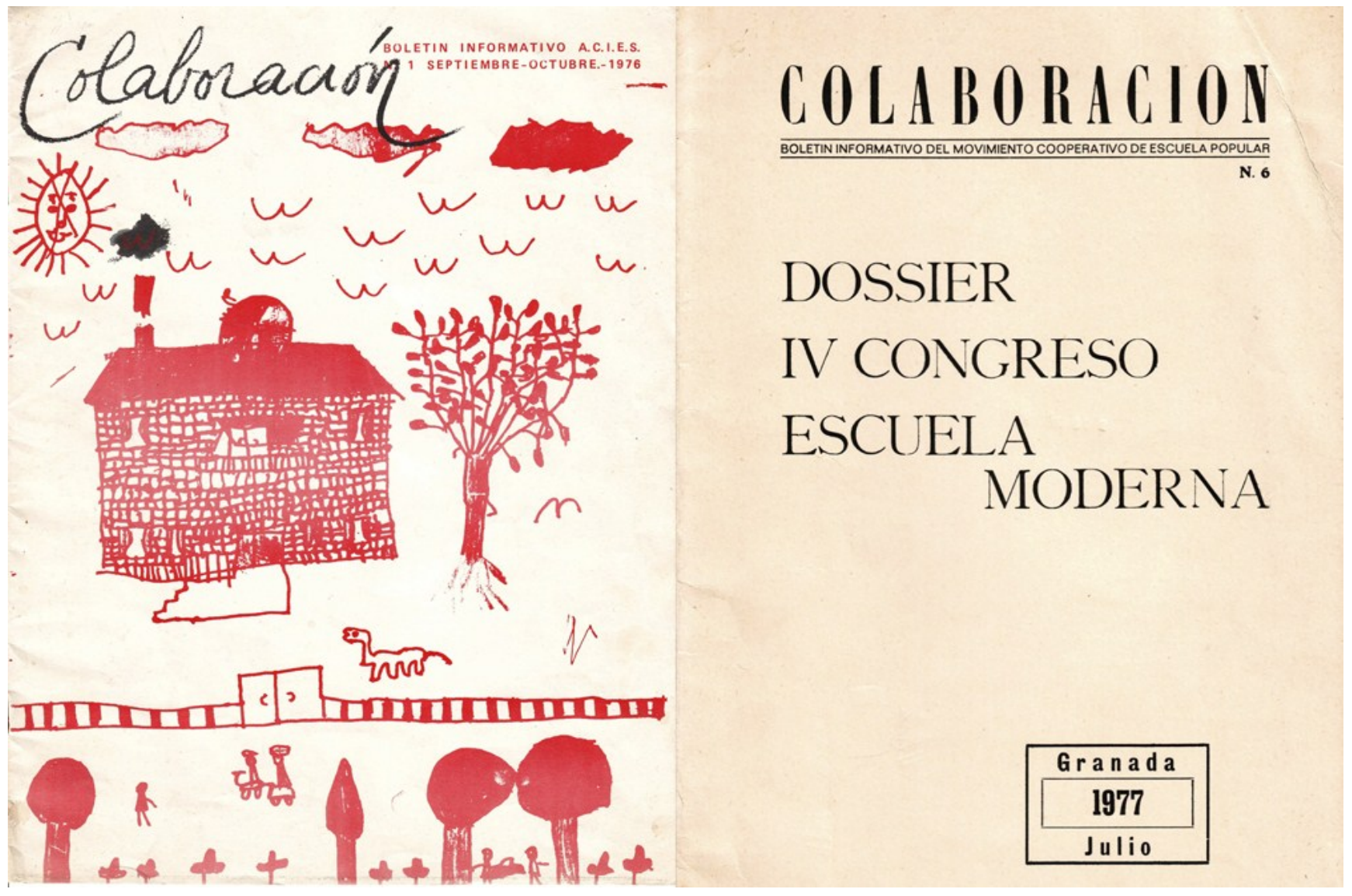

The spanish transition to democracy and the Movements for Pedagogical Renewal

In Spain in the mid-1960s, the earliest signs of an incipient - though tentative - process of social and cultural opening up and modernisation. Thus, when the country took part in the third wave of international democratisation (Huntington, 1990) in 1975, there was an obvious divergence between the intentions of the Franco administration and the needs and aspirations of the general populace, who were increasingly open to the outside world and receptive to other, more democratic, more European ways of life. Part of this was manifested in the political arena in the form of the first democratic elections (1977), won by the Unión de Centro Democrático (UCD); the Moncloa Pacts (1977); the Amnesty Law (1977); growing social mobilisation; the Constitution of 1978; and the first major change in direction of government (1982), in the free elections which gave an absolute majority to the Spanish Workers' Socialist Party - Psoe.

The slow and lengthy process of transition to democracy made itself felt in a number of ways in the field of education. Four milestones are of particular importance, because of their meaning and their significance: the schools pact, the university student mobilisations, popular 
education and the resurgence of the movements for pedagogical renewal. Indeed, the Ley General de Educación (1970) meant, firstly, the achievement of a schools pact that would facilitate the construction of a clear legal framework which was relatively flexible and somewhat more inclusive, and secondly, the pedagogical and social modernisation of the State-run education system which - according to international reports - had, amongst other things, to be capable of delivering schooling for everyone, of extending the reach of compulsory and free education, and of turning education into the main tool used to raise Spaniards' level of culture and facilitating the social ascension of broad sectors of the population. The schools pact, after intense debates at the sessions in which it was drafted, was consolidated and adapted to the new democratic way of life through the 1978 constitutional referendum (Colom Cañellas, 2011; Hernández Beltrán, 2002, 2007, 2008a, 2008b; Mayordomo Pérez, 2002, 2011; Puelles Benítez, 2002).

In parallel to this transition, and perhaps in a more lively and radical way, other transitions also took place, which greatly contributed to the democratisation of public life in Spain. As happened in Argentina, Brazil, Chile, Greece, Portugal and Uruguay, amongst others, the universities became strongholds of relative and minimal, though undeniable, freedom; the university was the main underground lab in which democracy was designed and fashioned, and acted as one of the catalysts for the political, social and cultural transformations. From the mid-1960s onwards, student activism and organised mobilisations often under the leadership of professors - steadily grew in magnitude and, over the course of the next two decades, they became key factors in the triumph of the processes of dismantling the dictatorships (González Calderón, 2015; González Gómez, 2015a; Henriques, Marchao, Mourato, 2015; Hernández Huerta, González Gómez, 2014; Hernández Huerta, Ortega Gaite, 2015; Karamanolakis, 2015; Markarián, 2015; Mota, Ferreira, 2015; Rocha, 2015; Rodríguez, 2015; Soler, Elías \& Portillo, 2015; Torgal, 2015; Toro Blanco, 2015; Vasconcelos Fernandes, 2015).

In Spain, university students were at the forefront of the anti-Franco struggle; they represented one of the population sectors most strongly committed to the democratisation of social, political and cultural life in the country; who connected with and felt solidarity with the workers' cause and carried out activities to improve literacy and promote socio-cultural dynamism and fundamental civic participation. The student movements of the 1960s, which reaped notable victories in dismantling the Francoist organisational and representational structures of the universities, also helped - at least in the education departments and teacher-training schools - to generate a certain critical pedagogical spirit in those who would, in the near future, be practicing educators in the country's schools. Thus, little by little, step by step, an educational environment was created which was favourable to the emergence and activity of the MRPs (Carrillo-Linares, 2015; González Gómez, 2014, 2015b; Groves, 2013b; Rodríguez Tejada, 2015; Rubio-Mayoral, 2015).

Popular education, for its part, underwent a significant transformation - at least among the ranks of the most advanced and progressive. The principles, means and ends were substantially altered - partly due to the influence exercised by the popular education movement which, in those decades, was gaining strength in Latin America (particularly under 
the leadership of Ivan Illich and Paulo Freire, who were two of the most visible and representative figureheads). Thus, various types of educators began to employ politicopedagogical ideas and practices aimed at the emancipation of people and social groups, and the construction of a fairer, more democratic society. Freire's influence in Spain was singularly intense, leaving his mark on the working priest movement, on certain MRPs such as the Movimiento de Renovación Pedagógica de Educadores Milanianos, legally set up in 1982, on street-education initiatives (such as those run by Enrique de Castro, Enrique Martínez Reguera or José Antonio Montull) and, especially, on adult education. In this latter area of activity, Freire's work was particularly seminal in the construction of the identity of educators, and in establishing the meaning, significance and goals of education (Bruno-Jofré, 2016; García Madrid, 2002, 2003, 2004; Groves, 2011b; Hernández Huerta, 2004; Igelmo Zaldívar, 2009, 2016; Martín González, 2004, 2006; Tapia, Martín González, 2004).

The third of the undercurrents active during the transition was the Movements for Pedagogical Renewal (MRPs). Despite the Franco administration's efforts to stamp out all remnants of the previous republican regime or the influence of the New School and Progressive Education movements, employing various kinds of secrecy, groups of teachers and individuals survived who were committed to revitalising the schooling system and using it as a tool to transform society. During the Civil War (1936-1939) and in the 1940s, the New School was condemned to ostracism, for which purpose the regime employed an effective system for repressing the teaching body - particularly involving administrative purging. During the next decade, the new generation of Spanish educators again took up some of their guiding principles, but reformulated them to adapt to the requirements of the social and political environment. Later, in the 1960s and 1970s, we see a certain connection of the teachers with the original most forward-looking pedagogical ideas of the first three decades of the $20^{\text {th }}$ Century, reflected in the professional didactic press, in legal texts and in the culture at school. Finally, the MRPs, from the beginning of the political transition until 1983 (when their campaign began to lose momentum), played a protagonistic and active role in the processes of technical modernisation of the schooling system, in the democratisation of the educational structures, in the expansion and increasing of the quality of public, pluralistic and egalitarian education, and in the social and cultural dynamisation of broad sectors of the population; those aspirations in education and the rejection of the dictatorship were the unifying aspects for these movements, which, furthermore, displayed a wide range of political, ideological and trade-unionist outlooks, and strategies to influence reality (Caride Gómez, 2011; Codina, 2002; Groves, 2014a, 2014b; Hernández Díaz, 2011, 2014; Hernández Díaz \& Hernández Huerta, 2007; López Martín, 2002; Pozo Andrés \& Braster, 2006, 2012).

Amongst the most active, dynamic and populous of the MRPs at the time was the Freinet Movement which, clandestinely, began labouring to construct a true popular schooling system - publicly-run, lively, democratic and with a marked political and social nature. This system was brought about through the use of simple and economical teaching techniques, which placed the child at the centre of the pedagogical activity, bringing him into direct contact with his surroundings, and shaping him into a critical, free and responsible member of society. 
Furthermore, this teacher movement played an important role in fuelling political debate about education, and generating and driving forward a number of fundamental social initiatives which managed to fully involve the educational community around the school:

Acies, the acronym for Asociación para la Correspondencia y la Imprenta Escolar (a name which was carefully chosen to conceal the Freinet movement's agenda of gradual but major transformation during the days of the dictatorship), was the first organised alternative in the context of State intervention, holding pedagogical principles which were adopted by thousands of educators nationwide. (Hernández Díaz, 2011)

\section{Freinet's influence in Spain during the transition to democracy}

Célestin Freinet, from the very beginning, imbued the Cooperative de l'enseignement laïc - CEL -, and the French Modern School movement which fed into the CEL, with a distinctive international character. The movement soon grew beyond France's borders, attracting followers distributed widely across the globe - particularly in Europe where, during the interwar period, programmes employing Freinet's techniques were initiated in Belgium, Bulgaria, Denmark, Germany, Holland, Hungary, Norway, Poland, Romania, the Soviet Union, Sweden, Switzerland and the United Kingdom. Later on, after WWII, the Freinet movement found special welcome in Germany, Italy, Portugal and Spain (Beattie, 2002; González Monteagudo, 1988; González Roa, 1999, 2002, 2008; Hernández Huerta, 2012; Imbernón, 1982).

Thus, Spain was not immune to such influences. During the Second Republic (19311936), the winds of change (pedagogical renewal) that came along with the regime meant that the new didactic techniques from France were well received - particularly in rural schools. Thus, very soon, an incipient movement of Freinetian teachers emerged and, little by little, materialised as a cohesive whole. In a short space of time, it became a group of valiant and concerned educators, ready to collaborate and be in constant communication, organised aronund the Cooperativa Española de la Técnica Freinet - Spanish Freinet Techniques Cooperative -, capable of fighting for a truly popular school - lively, dynamic, adapted to the children's interests and needs, guided by common sense, renewed, open to the influence of the environment, capable of helping the child to develop "his personality as fully as possible within a rational community which he serves and which serves him [...] to create a harmonious and balanced society" (Freinet, 1972). In addition to incorporating the free text, the school printing press, school correspondence and other techniques into their teaching activities, Spanish educators followed in the organisational footsteps of the CEL, holding conferences, starting up children's publications and setting up their own means of communication, the bulletin Colaboración, la imprenta en la escuela - Collaboratión: the school printing press -, which was the official mouthpiece of the movement in its early days (Hernández Díaz, Hernández Huerta, 2009b; Hernández Huerta, Hernández Díaz, 2012; Hernández Huerta, Sánchez Blanco, 2013).

However, the promising career of the Freinet movement was cut short in July 1936. The Civil War had begun, and along with it, the executions, purges and exiles. This was the full stop which ended the early Freinetian experiment in Spain: 15\% of teachers were exiled to 
Europe and Latin America; 25\% suffered interior exile - repression whilst being allowed to remain in Spain -; 6\% were stigmatised as persons hostile to the Regime; $36 \%$ were definitively expelled from the teaching service; and $3 \%$ were executed (Hernández Díaz \& Hernández Huerta, 2009a; Hernández Huerta, 2012).

It was not until the mid-1960s that Freinetian school culture re-emerged on the scene in Spanish teaching. This was achieved by the confluence of two circumstances: firstly the concern and intellectual risk of teachers who made contact directly, always in secret, with French counterparts in the Institut Cooperatif de l'École Moderne - Icem -; and secondly the return from exile of a number of teachers belonging to Spain's early Freinet movement, such as Josep Alcobé Biosca, which meant affiliating with the original project, thereby repairing the damage caused by the uprooting of the organisation and rescuing the memory of its pioneers.

In 1966, teachers in the Spanish provinces of Valencia, Guipúzcoa and Barcelona participated in the Icem Conference, held in Perpignan, France. At this pedagogical event, direct contact was made with French teachers and with some of the exiled Spaniards who belonged to the Cooperativa that operated during the Republican period. Upon their return from France, the teachers connected with others from Asturias, Santander and Bilbao whom they thought might be interested in incorporating the principles of the École Moderne into their daily activities. Thus, informally but with a considerable dose of passion, enthusiasm and eagerness, the earliest Freinetian networks were gradually constructed (Costa Rico, 2010; Fernández Sarasa, 2015; González Monteagudo, 1988, 2013).

During the late 1960s and early 1970s, Spanish teachers stayed in communication and direct contact with the French group, who supplied them with didactic materials and publications, and guided them in schooling practices with the techniques and principles of France's Modern School. Yet shortly afterwards, the idea and the need to organise gradually emerged - to organise like the rest of the groups in the European area had done. Finally, the idea became concrete in June 1973. The name which the teachers gave to their organisation, in light of the political circumstances, was deliberately free of ideological connotations, referring only to its professional nature: Association for Correspondence and the School Printing Press - Acies. However, it was not long before the true stance of the Freinet movement was seen in the organisation's name. In 1977, when Spain was already in the full throes of political transition, Acies was renamed Popular School Cooperative Movement MCEP - (Groves, 2008; Zurriaga, 1979b), which more closely reflected the commitment that teachers had acquired toward a popular public schooling system, capable of building a fairer, more democratic, solidarity-oriented future:

Our intention is not to define, a priori, what the child we educate will become. We do not prepare him to serve and perpetuate the world of today, but instead to construct the society which guarantees his development in the best possible way. We refuse to subjugate his spirit to any unyielding, pre-established dogma. (VV.AA, 1979) 
We are working towards their becoming aware, responsible adults, so they can construct a society where there is no oppression and exploitation of people by others. (Acies, 1979)

The strength, drive and dynamism of Acies/MCEP meant that the principles of the French École Moderne gained a protagonistic role and a significant presence on the broader scene of Spanish MRPs; in a manner of speaking, the way was led by Rosa Sensat. This coincided with the return of a number of pioneering teachers from exile. Both of these things meant that the professional educating community began to echo the discourse of the Spanish Freinet movement and the driving ideas behind it. Thus, the Publisher Editorial Laia (Barcelona) began to publish translations and reissues of the work of the French educator. At the same time, news about the École Moderne and about the Spanish group appeared in specialist periodicals, such as the journal Cuadernos de Pedagogía, which printed a number of short but seminal texts to set the Freinet movement back on its early trajectory, and thus mitigate the generational estrangement with which it had re-emerged. That journal's interest in the educational principles of the French pedagogue was clearly demonstrated in its $54^{\text {th }}$ issue, whose monographic topic was devoted to Freinet's pedagogy (Alcobé, 1975, 1979; Cuadernos de Pedagogía, 1979, 1980a, 1980b; MCEP Grupo Territorial de Granada, 1977; Zurriaga, 1979a). These two things resulted in broader dissemination and an increased presence of Acies/MCEP on the educational scene in Spain.

Amongst the multiple projects and varied activities carried out by Acies/MCEP, two are of particular note, which exemplify the Freinet movement's two arenas of action - pedagogical and political - and the principles of communication, collaboration and cooperation which inspired it: the pedagogical conferences and the journal Colaboración. The initiatives for teacher training and further training were also theatres in which active struggle against the Francoist regime took place. These initiatives manifested themselves in two ways: firstly, in the regular attendance of teachers and direct participation in the organisation of escuelas de verano (summer schools) - the most emblematic of the attempts at pedagogical renewal in the late Franco period and the transition, set in motion by the Asociación Rosa Sensat; secondly, in the national and international conferences and local meetings between the different Freinet organisations (Hernández Huerta; Groves, 2013).

From the very beginning, the members of Acies made sure to keep up to date with the ideas and advances in education in other countries in Europe. In keeping with Freinet's desire for internationalisation, they began to take part in conferences abroad, including: the Encuentros Internacionales de Educadores Freinet - International Meeting of Freinet Teachers, known as Ridef for its French title - held in Plock, Poland in 1976 and Lisbon, Portugal in 1977; the international École Moderne Conference in Rouen, France in 1977; and the International Conference staged by the International Federation of Modern School Movements - Fimen -, in Delft, Holland in 1981. These trips helped them to strengthen their relations with the parent group in France, to forge connections mainly (though not solely) with 
their counterparts in Italy, Poland, Holland and Portugal, and also to establish contact with other pedagogical groups. In addition, they facilitated the exchange of ideas and politicosocial opinions with other teachers, thereby enriching the democratising activities carried out in Spain.

Furthermore, the free and dynamic work of Acies/MCEP, following the model of the French group, very soon began to result in concrete activities aimed, primarily, at the members of the Freinet movement, such as: four Iberian conferences on Freinet techniques, between 1969 and 1972; nine Acies/MCEP conferences, held annually between 1974 and 1982; and innumerable seminars and local activity days staged by the organisation's regional branches (Costa Rico, 2010; Groves, 2009; Zurriaga, 1979c). Worthy of special recognition are the III Congreso de Acies (Salamanca, 1976) and IV Congreso de MCEP (Granada, 1977 ) - the latter because it was at this event that Acies became MCEP, and the former because it marked the point at which the general agenda of the Freinet movement was drawn up:

We are keen to establish and maintain collaborative relations with all organisations and individuals working towards a schooling system which serves the interests of the people. This cooperative work shall be rooted in the following: - cooperation between teachers in the furthering and exchange of methods and experiments carried out in the course of our teaching duties. This cooperative work between teachers tends to promote cooperative work between the students in different schools, using inter-school correspondence as a method. - We are a fundamental institution accommodating any and all educational professionals, regardless of their political leanings, provided they identify with the charter of the Modern School, and that charter is the accumulated product of our cooperative experiences in transforming the schooling system. - At an international level, we are members of the Fimen. (Acies, 1979)

The three fora of debate and further training became spaces for political education, pedagogical experimentation and professional development - laboratories for the transformation of the world into something better through education, culture and civil participation. Thus, after the Escuela de Verano held in Aragón (1977), Freinet's disciples, in keeping with the critical theories of education at the time, concluded that education is not ideologically neutral, but instead "is in the service of some particular interests" (VV.AA, 1977b). That same year, during the assembly at the I Jornadas Pedagógicas de Asturias, teachers roundly condemned the Franco dictatorship's authoritarianism and elitism:

Those attending the I Jornadas Pedagógicas de Asturias, having come together in Assembly, manifest their disgust at the education system which has, up until now, been authoritarian, centrist and classist, insofar as it replicates the existing social structures. Thus, they propose a PUBLIC DEBATE about the current state of education, with a view to finding a democratic alternative with contributions from all interested parties: parents, neighbours, teachers, pupils, and political and cultural organisations. (V.AA, 1977a) 
Acies/MCEP's other major project was the journal Colaboración. That publication helped to erode the Franco regime's pedagogical policies and to develop critical trains of thought about education, culture, society and politics, as did other contemporary publishing initiatives, including, notably, Perspectiva Escolar, published by the Asociación Rosa Sensat, Cuadernos de Pedagogía, Acción Educativa, Guix, Reforma de la Escuela and Infancia y Aprendizaje, amongst others. That publishing environment, also, was indicative of the gradual consolidation and incorporation of the professional pedagogical press into school culture (Hernández Díaz, 2011, 2015; Hernández Díaz \& Hernández Huerta, 2013).

The founding of the journal was symptomatic of the fact that the movement was taking shape and consolidating, because in bringing the project to fruition, over 320 teachers contributed, from a number of different regions of Spain: Alicante, Almería, Aragón, Asturias, Badajoz, Barcelona, Cádiz, Cantabria, Ciudad Real, Ferrol, Granada, Las Palmas, León, Lugo, Madrid, Malaga, Murcia, Salamanca, Seville, Valencia and Vizcaya. The first edition corresponded to the months of September-October 1976, and the rest were published, more or less regularly, at the rate of one every two months, except when editorial requirements and interests necessitated the altering of the periodicity. In total, 53 editions were published. All of these were published by Acies/MCEP, printed in Granada and distributed by the territorial branch of the movement in each area. The number of pages varied from one edition to the next, ranging between 20 and 50, depending on the material received and the financial situation at the time, which also determined the number of contributors to each edition. The sections which made up the publication varied over the years; their number steadily increased, until the makeup stabilised midway through the journal's run, as follows: front page or editorial, monographical article, experience articles, interview, collaborations, pre-school material and reading material. The subjects discussed therein were many and varied, covering a broad spectrum of pedagogical, political and social interests.

Colaboración attested to the marked trans-national nature of France's École Moderne: in the Spanish group's publication, a significant amount of page space was reserved for international communication and collaboration; articles were received from foreign teachers mainly in France and the United Kingdom - relating their experiences with Freinet's techniques. In addition, the international communication network remained in place for the incipient movement gradually being built up by Spanish teachers, which, at the start of the 1980s, included participation from over 100 French schools, in addition to the Spaniards themselves.

Ultimately, the journal became another tool for the democratic construction of pedagogical thinking, for the comparison of ideas and opinions, for critical reviewing of education, culture and society, and also a catalyst of the contributions of the members of the Freinet movement to the political debate about the fundamental rights and freedoms which were being hotly discussed in Spain during those years of transition. 


\section{Contributions by Acies/MCEP to the democratisation of education in Spain during the transition}

During the transition, the MRPs had a markedly-political nature. In addition to modernising all areas of education, their intention was to bring democracy to the public and private fora in life in Spain, through various forms of social, cultural and civic participation. Thus, teachers' area of activity should transcend the boundaries of the school, linking it with its surrounding environment and turning it into a catalyst for social, cultural and political change. At the same time, the idea of teaching was gradually replaced by that of education, which was broader, richer in meaning and more versatile and which, in turn, took on a new dimension and underwent a metamorphosis, due mainly to the revival of the principles of liberty, equality, social fairness and solidarity in the efforts of the Escuela Nueva. Ultimately, these principles resulted in the democratisation of day-to-day life for wide sectors of the population (Groves, 2012, 2014a).

Spain's Freinet movement was no exception. From the very start, the teachers endowed their upstart organisation with a clear ideological and activist backdrop. This was manifested in the so-called Letter from Mollet, 1972, drafted during the course of the IV Encuentro Peninsular de las Técnicas Freinet, held in Mollet (Barcelona):

Educational action is an element, but only one element, of an absolutely
essential social revolution. [...] the social and political context, the working and
living conditions of parents have a significant influence on the education of the
younger generations. For this reason, our aim is to demonstrate to educators,
parents and all friends of the school the necessity of taking action socially and
politically, alongside educational workers, so that teaching can actually serve
its true purpose of educating our youth. [...] We labour so that our pupils
become mindful, responsible adults who will build a world where war, racism
and all other forms of discrimination and exploitation are prohibited (Zurriaga,
1979c)

Shortly afterwards, during July 1976, with the dictator having recently died, the III Congreso del Movimiento Cooperativo de Escuela Popular was held in Salamanca. As a result of the conversations and debates which took place at that conference, a Declaration was drafted, in which the movement and the schooling system were linked, inextricably, with social and political mobilisation to make the world a better place - a fairer, freer place with mutual solidarity:

Spain's Escuela Moderna - now known as MCEP - is the organisation of teachers which, by way of cooperative and critical work and research, seeks or strives toward the renewal of the school system - a constant renewal which incorporates the school into the fight for the liberation of the popular classes [...] We hold education to be: the development and liberation of the individual, so that the cooperative in solidarity will gradually create a society with no oppression, until social class is eliminated. This will only be possible in a socialist society. Living in a situation of freedom limited by the group, selfmanagement, use and control of certain common assets, critical of the reality surrounding oneself and active participation in that reality. [...] Furthermore, we aim to eliminate an education system which serves as a vehicle for the 
extension of the capitalist ideology to all levels of society, with a view to legitimising, perpetuating and strengthening the system. [...] We reject the illusion of education which is sufficient in its own right, beyond the main social and political streams which condition it. We are part of the struggle of the working class and working people for the construction of a class-free society. [...] Our educational action aims to interpret the interests and values of the people, with education that does not perpetuate the economic and social structures based on exploitation or perpetuation of the class system. (Acies, 1979)

These principles infiltrated the daily practices of Freinetian teachers, which was reflected, amongst other things, in the committed involvement and participation in the community in which the school was located, thereby managing to lend dynamism to the social, political and cultural life of that community. For example, a number of local community newspapers were set up, as were amateur dramatics societies, and the activities carried out by school teleclubs were extended; in some cases, the teleclubs became atypical nuclei of power - particularly in rural populations. With this aim in mind, teachers made use of their own abilities and collaboration with parents and certain sectors of the forces active in the areas (Groves, 2008, 2010).

Teachers' activism can also be seen in the specialist pedagogical press, which helped to fuel the political and professional debate about certain key points of the pre- and postconstitutional parliamentary debates, such as the general objectives of education, the right to education, the freedom and form of education, and the degree and means of participation of families in the education system. Those rights and freedoms were embodied in the 1978 Constitution - essentially in Article 27 - and developed by the first democratic governments of the UCD and Psoe, though not without intense political friction, student mobilisations, activity of trade-unions and educational professionals, and pedagogical debates. Small wonder, then, that the teachers took up their principles on this issue, took a stand and critically fuelled the professional debate about these key aspects of the process of modernisation and democratisation of the education system in Colaboración (1976-1985).

The members of Acies/MCEP viewed education as a first-order public asset. They adhered to the various declarations and conventions of international organisations and institutions which recognised education as a fundamental right, whereby citizens could demand positive action on the part of the states to ensure access to basic education (free and compulsory); admittance to education centres with no more limitations than those established for reasons of public interest; to receive objective evaluation which facilitates access to other levels of education and to receive education free from all kinds of discrimination. Furthermore, the school, if it truly were a genuine popular school, must bring together a number of specific characteristics: it must be public, unique, free, secular, varied, mixed, decentralised, independent, based on scientific criteria, fed by the critical analysis of reality, and closely connected with the social and cultural environment and with the world of work (MCEP, 1977). Ultimately, the public schooling system, 
was understanding that the school was in the service of certain people and of a collective, rather than a political regime; that school work was a constant investigation, which analyses the surrounding reality; which brings together manual and intellectual work, in which the student is understood as a person capable of training himself and controlling himself, which is not repressive, which develops solidarity, etc. (Acies, 1977b)

Institutionalised education, though, must go further in its principles. Freinetian teachers considered education to be one of the main ways to achieve the democratisation of states, the modernisation of peoples and societies and the emancipation of persons and social groups at a clear social, cultural and economic disadvantage. The goals of education, consequently, must be aimed at encouraging the acquisition and development of general culture, promoting equal opportunities, developing the students' abilities and capability as much as possible, and the sense of social responsibility and ethics in favour of the common good, and be propitious to freedom of choice for the children and adolescents, who needed to become the backbone of the educational process (Acies, 1977a; Emilio, 1977).

Therefore, the classroom was set up as a laboratory for democracy where, little by little, children and adolescents discovered the limitations of their own freedom and others', taking control of and responsibility for their own lives. With this goal in mind, working atmospheres were created which facilitated the free comparison of ideas and opinions, critical thinking, independent construction of knowledge and experience, community life and organisation of work in the spirit of cooperation and solidarity, so that, through direct action, the students could become free and independent citizens, interiorising a new social and political culture which was democratic, fair and supportive (Acies, 1977c; Colegio Nacional Jose Mestres Busquets, 1978; MCEP, 1977). Therefore, teachers, both at school and beyond, had to "encourage those educational moments which have a high value in themselves, and be very vigilant to detect where the educational act occurs and where behaviour becomes routine" (Barre, 1979), and ultimately eliminate the obstacles which could hinder that way of working and building the future:

We, revolutionary pedagogues, are committed to breaking [...] the indoctrination; the dead science; the soiled, violated culture; the institution of the school; the perpetuation of hierarchical arrangements; competitiveness; capitalist society and everything that it represents. (Pereira, 1978)

Hence, Freinetian teachers participated in the international debates about schooling which were taking place because of the global crisis in education. Thus, they directed harsh criticism against national governments and international organisations in charge of encouraging the development and implementation of the right to education. On the one hand, they decried the excessive slowness with which education systems were adapting to the needs and aspirations of society at the time, and urged everyone involved to promote and implement projects for the renewal and revitalisation of educational systems which, in addition, were focused on increasing the rates of social fairness (Acies, 1977c). On the other hand, they aimed severe criticism at the structure, principles, means and ends of the schooling system, considered to be in the service of the capitalist system: 
It is truly shameful to consider the education systems that exist in the world. Simply put, in light of the reality with which we are faced, the function of our education system is to indoctrinate children so they will perpetuate the social makeup currently in force. The child is subjected to the most diverse kinds of mental torture to make him "understand" that things are and must be what we say they are and must be. Clearly, in the majority of cases, sooner or later, the children end up "understanding" that we were right and that the best thing for them to do is to obey us, because therefore everything will go easier for them and they will ultimately "triumph" in life. A small number of people may think that it is possible that we are wrong, and we shall call them rebels, incorrigible, undesirable, etc., we shall marginalise them, end of story [...] the whole of this process [...] which is brutally accurate [...] is basically due to an error of principle. In our education systems, everything is said, everything is set... from beginning to end. Therefore, for the child, his only option is to go down the dead-end street with no hope of rescue. The children who walk down that road, we say are "educated". (Barre, 1979)

The defence of the popular public, secular school clashed head-on with the most liberal and the most conservative principles in Spain at the time, which called for recognition of the freedom to set up teaching centres and the possibility that private centres could establish links with the public authorities, provided they conformed to the stipulations in the legislation in force, because only in this way could they guarantee, on the one hand, the right of families to choose the most suitable education for their children and, on the other, given the rising cost of education and the scant financial viability - of obligatory education, at least the effectiveness of the manifestation of free enterprise on the educational level (MCEP, 1978b).

This way of understanding freedom of education was perceived, within the Freinet movement, in the same way as in the most progressive and advanced political groups, trade unions and pedagogical renewal movements of the time: as one of the expressions of the capitalist system and as an ideological stronghold of the Catholic church and the Franco regime. This outlook included a number of risks which could compromise the quality of the public education system and the consolidation of the democratisation and secularisation process in the medium and long term - two of particular note: firstly, diverting public funds into private education meant taking them away from the budgets intended for public schools. This resulted in a reduction in the efficiency and operational capacity of the State-run education system; secondly, with the freedom to establish the central ideology recognised, it was possible to fund schooling centres where ideological, religious or financial criteria could exert a discreet but definite influence when it came to accessing them (Fernández, García \& López, 1980; MCEP, 1978b). Thus, Acies/MCEP advocated the recognition of the freedom to set up educational centres, but on condition that it did not imply an economic compromise for the public administration

private education is, in the majority of cases, a denominational education, which corresponds to a single ideology training open-minded and diverse students, who would be future religious and political activists. On the other hand, in private education, there is also economic discrimination; it is not designed as a public service, but instead as a business. Therefore, its centres 
are opened wherever there may be potential customers: in those areas where there is greatest financial capacity [...] Furthermore, we doubt that subsidies will be sufficient to make private education free, as, if they are not going to charge anything - say, for instance, with Basic General Education (E.G.B.) -, they will always manage to invent other concepts (school lunch, transport, heating, maintenance costs, special classes, etc.), which will drive up monthly costs to levels which not everyone will be able to pay. If we examine where the students at these centres come from, we shall soon see that many of them spent their pre-school years at the same centre, and as that educational level is not free, it was more financially-comfortable children who accessed this service. Here we see the clientele of the private schools [...] those who want a denominational education, or one specific to a given social class, can choose it so long as they can pay their way. (MCEP, 1978b)

Very quickly, Freinetian teachers became aware of the fact that modernisation of education, improvement of the infrastructures, restructuring of the public administration in charge of education, modification of the laws and statutes, extension and improvement of education, recycling of teachers or of their actual activity in the classrooms were key aspects in transforming the reality in which they lived - key, but not sufficient. In order to 1) reshape the pedagogical ideology which had taken shape in Spanish schools over the course of several decades, and 2) ensure that education was in the service of the people and could not betray itself, in a struggle against the relations of domination and the consumer model that were characteristic of the capitalist lifestyle, it was also crucial to influence the whole of Spain's social, political and cultural framework. It was essential to seek out participation, collaboration and mutual understanding with the popular school on the part of groups and organisations whole political and social aspirations and motives matched those of Acies/MCEP:

This struggle requires an effort not only by a movement of educators; it is necessary to raise awareness of this problem amongst workers and the social surroundings, and involve their organisations in it: parties, trade unions, neighbours' associations, parents' associations, democratic institutions [...] The times which we are now living through, the expectations that are being created, the receptiveness which we may find, mean that now is a propitious occasion to promote and strengthen these ideas [...] We reinforce the training of pedagogical teams, educational research, the primacy of educational matters over administrative ones, decentralisation, democratisation, etc. We shall not fall into the pedagogical illusion of being locked up in our classes or in "our" movement; let us weave an overall political framework so that our project of a Public School [...] can be a reality, rather than one more document in our archive. (Navarro, 1982)

Indeed, the school was considered to be a public institution in the service of the community and a living organism, constantly changing and growing, always aware of the need to adapt to the social and cultural environment which lends it meaning and significance. For this reason, residents, visitors and collaborators with the school should, amongst themselves, establish clear, efficient channels and strategies of communication, collaboration 
and cooperation which would result in mutual social and cultural enrichment, and the construction of a popular, critical and active schooling system (MCEP Grupo Territorial de Madrid, 1979):

We believe the important thing is the sense of group created, and the feeling that the school is something that is ours, which provides a major service to the community, and that therefore we must take care of it, improve it and demand that it have the optimum conditions in accordance with the services it provides. Yet at the same time, as an institution in the service of the people, the people are entitled to expect that the product offered by the school - education - be unadulterated, and they have the obligation and the right to monitor its quality; hence our recommendation of this close link between the parents and the school and everything related to it. We maintain that parents' role in the school is no less important than that of the teachers themselves. (Acies, 1977d)

The participation and presence of families at the centres, in addition to a way of developing an aspect of the right to education and enforcing one of the facets of freedom of education, was a core element in the educational activity of schools following Freinet's ideals. Collaboration between the two institutions should bring about a notable increase in the degree of democratisation of education, as well as a fruitful exchange of technical and cultural instruments between teachers and parents, with the aim of designing and building education together (MCEP Grupo Territorial de Madrid, 1979). Amongst other things, it was considered appropriate for parents to be kept informed of the changes that had been introduced in school culture, and should feel themselves to be a part of those events:

It is necessary to increase the amount of contact with parents and with workers, who do not recognise, in our practice, the image of the school which they held. Quite legitimately, parents want their children to succeed, and want for them the type of education which, in their eyes, should help them to climb the social ladder. It is important to demonstrate to them that this conceptual education, based on verbalisation, is damaging to most children [...] The methods to which we are opposed, and which parents find reassuring because they are the methods with which they are familiar, although they have not been allowed to dominate the learning experience, are limited to memorisation, cause automatic behaviour, conditioned reflexes, and leave no room for creativity [...] all of this must be explained patiently to the parents, as must the importance that we attach to exchanges, to flows which are established in the group (the natural method cannot be taught in concrete lessons), to the pleasure which comes from living together which, contrary to the widely-held idea, does not impede work [...] It is crucial that parents know that our desire is to find the child again, and that our agenda is to shape complete human beings. (MCEP, 1978a)

Despite teachers' efforts to involve families in life in school, on occasion, they bemoaned the scant success that these initiatives had - particularly the Parent and Student Associations - APAs -, where the habit had not yet been established of taking an active role in the process of formal and regulated learning by the children and adolescents. Thus, the parents and legal 
guardians refused to participate in additional and extra-curricular activities. They ignored the proposals of collaboration with the centre, or showed themselves to be resistant to the schooling innovations imported from France (MCEP, 1978a; Quintero, 1978):

APAs had not worked as it had been hoped they would, for one or other of the following reasons: a) Lack of awareness-raising among the parents. b) Lack of accustomisation to participating. c) The immediate politicisation of everything.

d) A reactionary directive council. e) The indifference of certain colleagues. (Acies Grupo Territorial Murcia, 1977)

\section{Conclusions}

During the transition to democracy, Spain experienced the emergence of an environment propitious to pedagogical experimentation. Thus, gradually, from the twilight of the Franco dictatorship - first in a clandestine manner and then legally - various Movements for Pedagogical Renewal - MRPs - emerged. These groups of teachers, in their desire to modernise the schooling system and transform society into something freer, fairer and more democratic, connected with the principles of the republican education system and with the New School and Progressive Education movements, whose pedagogical ideas, and especially their politico-social ideas, had been officially consigned to obscurity during the Franco regime's time in power.

The group of Spanish teachers which adhered to the postulates of France's École Moderne was one of the most lively, dynamic and activist MRPs. This restarted the trajectory of the first stage of the Freinet movement in Spain (1926-1939), cut short by the Civil War and the long years of dictatorship which came in its wake. Following in the footsteps of the pioneers, of the Institut Cooperatif de I'Ecole Moderne - Icem - and of the rest of the Freinetian groups in Europe, Spanish teachers organised in 1973 to form the Association for Correspondence and the School Printing Press - Acies - which, in 1977, changed its name to Popular School Cooperative Movement - MCEP -, which better reflected the spirit and the ideals from which it had arisen and which fuelled its activity.

The development of Spain's Freinet movement had a dual nature: pedagogical and politico-social. On the one hand, the teachers were trying to revitalise and modernise the schooling system, for which they imbued their daily practices with economic techniques, which were simple and had major educational potential, manifested in alternative ways of organising at school and more democratic styles of education/learning, based on communication, cooperation and collaboration between all the residents of the educational institutions and the immediate surroundings. On the other hand, they accompanied the pedagogical activity with a complete programme of political, social and cultural transformation, which manifested itself in various forms of political and trade-unionist activism, and participation and organisation of base groups, both in rural areas and in the urban areas of the provincial capitals.

The result was the creation of spaces for learning and experimentation with other forms of community spirit. Of special importance among these were the journal Colaboración the organ of expression of Acies/MCEP - and national and international conferences, seminars and activity days aimed at improving teaching practices and professional 
development, whether organised by some branch of the international Freinet movement or by other MRPs. These initiatives demonstrated that, in spite of the difficult times, which were still hard and always uncertain, it was possible to create free and independent spaces for communication and pedagogical collaboration, with the aim of modernising and democratising education and, by extension, the political, social and cultural surroundings.

For its part, the starting up of Colaboración, in a manner of speaking, marked the beginning of a new stage in the path of the Spanish Freinet movement. It was one of the indicators of the movement's pedagogical, social and political maturity, of the fact that the organisation was slowly taking shape, and that it now had enough members to instigate initiatives of greater importance and broader reach. As it was a journal controlled by teachers and heeded by teachers not belonging to the movement, it also acted as an amplifier of the postulates of the French educator, thereby helping to disseminate the Freinetian seed and facilitating its infiltration into the culture of Spanish schools at the time, assisting with the renewal of the principles, means and ends of the school system.

In addition, the journal was a forum where, besides exchanging technical/educational ideas, teachers developed ideas and politico-pedagogical discourses, which notably helped to clarify the movement's orientation and to fuel public debates about education. Thus, they favoured an emancipating model of popular education and of a public school which was unique, secular, democratic, inclusive, egalitarian and high-quality, capable of entering into contact with life itself and projecting beyond its strictly-administrative confines, contributing to the free, fair and supportive development of the community it served. For this purpose, they considered two things to be crucial: firstly, that public finances should be invested solely in the State-run education network, so that its operational potential is not harmed; and secondly, achieving participation, understanding and cooperation in the educational task of all the actors in the environment, which gave life, meaning and significance to the school - particularly the families.

These were among the most prevalent contributions of the Spanish Freinet movement to the democratisation of education, culture and society during the late Franco period and the transition to democracy. They were also other examples, which demonstrate the accuracy of one of the postulates of the founder of the École Moderne: ultimately, sooner or later, life and liberty will always find a way.

\section{Bibliography}

ACIES. Declaración de los derechos del niño. Colaboración, n. 3, 1977a, p. 9.

ACIES. Editorial. Colaboración, n. 3, 1977b, p. 2.

ACIES. Gestión escolar. Colaboración, n. 6, 1977c, p. 1-9.

ACIES. PALOMERAS: Autogestión en una Escuela. Colaboración, n. 5, 1977d, p. 12-14.

ACIES. Declaración del III Congreso de la Asociación Española para la Correspondencia y la Imprenta Escolar. Salamanca, 24 de julio de 1976. Colaboración, n. 1979, p. 5-8.

ACIES GRUPO TERRITORIAL MURCIA. Intercambio de experiencias la Rivera. Colaboración, n. 3, 1977, p. 15-21. 
ALCOBÉ, Josep. Herminio Almendros: un educador para el pueblo. Cuadernos de Pedagogía, n. 3, 1975, p. 30-32.

ALCOBÉ, Josep. Una pedagogía para el futuro. Cuadernos de Pedagogía, n. 54, 1979, p. $15-$ 18.

BARRE, Michel. Primera página. Colaboración, n. 15, 1979, p. 3.

BEATTIE, Nicholas M. The freinet movements of France, Italy and Germany, 1920-2000: versions of educational progressivism. Lewiston, NY: The Edwin Mellen Press, 2002.

BRUNO-JOFRÉ, Rosa. Educación popular en América Latina durante la década de los setenta y ochenta: una cartografía de sus significados políticos y pedagógicos. Foro de Educación, v. 14, n. 20, 2016, p. 429-451.

CARIDE GÓMEZ, José Antonio. La pedagogía social en la transición democrática española: apuntes para una historia en construcción. Educació i història: Revista d'història de l'educació, n. 18, 2011, p. 37-59.

CARRILLO-LINARES, Alberto. Universidades y transiciones políticas: el caso español en los años 60-70. Espacio, Tiempo y Educación, v. 2, n. 2, 2015, p. 49-75.

CODINA, María Teresa. Rosa Sensat y los orígenes de los movimientos de renovación pedagógica. Historia de la Educación. Revista Interuniversitaria, n. 21, 2002, p. 91-104.

COLEGIO NACIONAL JOSE MESTRES BUSQUETS. Un ejemplo de organización en la escuela. Colaboración, n. 9, 1978, p. 9-12.

COLOM CAÑELLAS, Antonio Juan. Ideologia i educació en el procés articulant entre el franquisme i la democràcia. Educació i història: Revista d'història de l'educació, n. 18, 2011, p. 13-36.

COSTA RICO, Antón. D'abord les enfants: Freinet y la educación en España 1926-1975 Santiago de Compostela: USC, 2010.

CUADERNOS DE PEDAGOGÍA. Tema del mes: la pedagogía Freinet. Cuadernos de Pedagogía, n. 54, 1979, p. 3-24.

CUADERNOS DE PEDAGOGÍA. Entrevista. Josep Alcobé. Cuadernos de Pedagogía, n. 71, 1980a, p. 23-25.

CUADERNOS DE PEDAGOGÍA. Freinet en una escuela estatal. Cuadernos de Pedagogía, n. 72, 1980b, p. 42-44.

EMILIO. ¿Qué es? Colaboración, n. 5, 1977, p. 2-3.

FERNÁNDEZ, Manolo; GARCÍA, Sofía; LÓPEZ, Gloria. Primera página. Colaboración, n. 21, 1980, p. 3.

FERNÁNDEZ SARASA, Carla. Transformación social y creación de sentido en los testimonios de maestros y alumnos de la segunda etapa del movimiento Freinet en España. Social and Education History, v. 4, n. 3, 2015, p. 287-308.

FREINET, Célestin. Por una escuela del pueblo. Barcelona: Laia, 1972.

GARCÍA MADRID, Antonio. Enrique de Castro: el cura del infierno del sur. Papeles salmantinos de educación, n. 1, 2002, p. 217-248. 
GARCÍA MADRID, Antonio. Tres conferencias de Freire y una charla abierta con los alumnos de la Universidad Pontifica de Salamanca (I). Papeles salmantinos de educación, n. 2, 2003, p. 237-269.

GARCÍA MADRID, Antonio. Tres conferencias de Freire y una charla abierta con los alumnos en la Universidad Pontificia de Salamanca (II). Papeles salmantinos de educación, n. 3, 2004, p. 303.

GONZÁLEZ CALDERÓN, Fabián. Mil días de la junta militar de gobierno: la metamorfosis subterránea de la educación chilena durante los primeros años de la dictadura militar (1973 1979). Cuadernos Chilenos de Historia de la Educación, n. 4, 2015, p. 34-61.

GONZÁLEZ GÓMEZ, Sara. Proyección e internacionalización de los estudios en la Universidad española del franquismo: revisión de la realidad de la Universidad de Salamanca. Espacio, Tiempo y Educación, v. 1, n. 2, 2014, p. 89-112.

GONZÁLEZ GÓMEZ, Sara. Universidad y transiciones a la democracia en la Europa mediterránea e iberoamérica (1970-1980). Presentación. Espacio, Tiempo y Educación, v. 2, n. 2, 2015a, p. 25-32.

GONZÁLEZ GÓMEZ, Sara. Universidad, franquismo y transición democrática: charlas con José Luis Peset Reig y Elena Hernández Sandoica. Espacio, Tiempo y Educación, v. 2, n. 2, 2015b, p. 337-354.

GONZÁLEZ MONTEAGUDO, José. La pedagogía de Célestin Freinet: contexto, bases teóricas, influencia. Madrid: Centro de Publicaciones - Secretaría General Técnica, 1988.

GONZÁLEZ MONTEAGUDO, José. Célestin Freinet, la escritura en libertad y el periódico escolar: un modelo de innovación educativa en la primera mitad del siglo 20. Hist. Educ. (Online), v. 17, n. 40, 2013, p. 11-26.

GONZÁLEZ ROA, Pedro Francisco. El movimiento de la escuela moderna portuguesa. Salamanca: Universidad de Salamanca, 1999.

GONZÁLEZ ROA, Pedro Francisco. O movimento da escola moderna: um percurso cooperativo na construção da profissão docente e no desenvolvimento da pedagogia escolar. Porto: Porto, 2002.

GONZÁLEZ ROA, Pedro Francisco. La influencia de Freinet en Portual: el caso de la escuela moderna portuguesa. In: José María HERNÁNDEZ DÍAZ. Influencias francesas en la educación española e iberoamericana (1808-2008). Salamanca, 2008, p. 585-592.

GROVES, Tamar. Maestros comprometidos: el movimiento Freinet durante el tardofranquismo y la transición a la democracia en España. In: HERNÁNDEZ, José Maria. Influencias francesas en la educación española e iberoamericana (1808-2008). Salamanca, 2008, p. 67-79.

GROVES, Tamar. El movimiento de enseñantes durante el tardofranquismo y la transición a la democracia 1970-1983. Madrid: Uned, 2009.

GROVES, Tamar. ¿Qué engaña más, la memoria o los documentos?: experiencias de la pedagogía Freinet en la escuela rural en los años setenta. Foro de Educación v. 8, n. 12, 2010, p. 171-173. 
GROVES, Tamar. Las escuelas de verano: una reforma educativa desde abajo. In: CELADA PERANDONES, Pablo. Arte y oficio de enseñar: dos siglos de perspectiva histórica. COLOQUIO NACIONAL DE HISTORIA DE LA EDUCACIÓN, 16, 2011. Anales ... El Burgo de Osma-Soria, 2011a, p. 145-154.

GROVES, Tamar. Looking up to Paulo Freire: education and political culture during the spanish transition to democracy. Paedagogica Historica: International journal of the history of education, v. 47, n. 5, 2011b, p. 701-717.

GROVES, Tamar. Everyday struggles against franco's authoritarian legacy: pedagogical social movements and democracy in Spain. Journal of Social History, v. 46, n. 2, 2012, p. 305-334.

GROVES, Tamar. El pasado, el presente y el futuro de una utopía: la escuela nueva y la renovación pedagógica. In: ESPIGADO TOCINO, M. Gloria; GÓMEZ FERNÁNDEZ, Juan; PASCUA SÁNCHEZ, María José de la; Luis SÁNCHEZ VILLANUEVA, Juan Luis; VÁZQUEZ DOMíNGUEZ, Carmen. La Constitución de Cádiz: genealogía y desarrollo del sistema educativo liberal. COLOQUIO NACIONAL DE HISTORIA DE LA EDUCACIÓN, 17, 2013. Anales ... Cádiz, 2013a, p. 845-854.

GROVES, Tamar. ¿Modernización o democratización?: la construcción de un nuevo sistema educativo entre el tardofranquismo y la democracia. Bordón, v. 65, n. 4, 2013b, p. 135-148.

GROVES, Tamar. Political transition and democratic teachers: negotiating citizenship in the spanish education system. European History Quarterly, v. 44, n. 2, 2014a, p. 263-292.

GROVES, Tamar. Teachers and the struggle for democracy in Spain, 1970-1985. New York: Palgrave macmillan, 2014b.

HENRIQUES, Helder; MARCHAO, Amélia; MOURATO, Joaquim. A democracia e o ensino superior politécnico português: o caso do Instituto Politécnico de Portalegre (década de 80 do séc. XX). Espacio, Tiempo y Educación, v. 2, n. 2, 2015, p. 173-196.

HERNÁNDEZ BELTRÁN, Juan Carlos. Educar en tiempos de transición: significación educativa de los pactos de la Moncloa. Aula: Revista de Pedagogía de la Universidad de Salamanca, n. 14, 2002, p. 143-154.

HERNÁNDEZ BELTRÁN, Juan Carlos. Parlamento y universidad en la transición a la democracia (1975-1982): el proyecto de ley de autonomía universitaria: radiografía de un desencuentro. Historia de la educación: Revista interuniversitaria, n. 26, 2007, p. 367-391.

HERNÁNDEZ BELTRÁN, Juan Carlos. La educación en la Constitución Española de 1978. Debates parlamentarios. Foro de Educación, v. 6, n. 10, 2008a, p. 23-56.

HERNÁNDEZ BELTRÁN, Juan Carlos. Política y educación en la transición democrática española. Foro de Educación, v. 6, n. 10, 2008b, p. 57-92.

HERNÁNDEZ DÍAZ, José María. La renovación pedagógica en España al final de la transición: el encuentro de los movimientos de renovación pedagógica y el ministro Maravall (1983). Educació i Història: Revista d'Història de l'Educació, n. 18, 2011, p. 81-105.

HERNÁNDEZ DÍAZ, José María. Asociacionismo y sindicalismo docente durante la transición en España (1970-1983). Aula: Revista de Pedagogía de la Universidad de Salamanca, n. 20, 2014, p. 135-158. 
HERNÁNDEZ DÍAZ, José María; HERNÁNDEZ HUERTA, José Luis. Bosquejo histórico del Movimiento Freinet en España. 1926-1939. Foro de Educación, v. 5, n. 9, 2007, p. 169-202.

HERNÁNDEZ DÍAZ, José María; HERNÁNDEZ HUERTA, José Luis. La represión franquista de los maestros freinetianos. Aula. Revista de Pedagogía de la Universidad de Salamanca, n. 15, 2009a, p. 201-227.

HERNÁNDEZ DÍAZ, José María; HERNÁNDEZ HUERTA, José Luis. Transformar el mundo desde la escuela con palabras: los cuadernos freinetianos de Barbastro durante la II República. Huesca: Gobierno de Aragón. Departamento de Educación, Cultura y Deporte y Museo Pedagógico de Aragón, 2009b.

HERNÁNDEZ HUERTA, José Luis. José Antonio Montull: un educador de calle con sentido. Foro de Educación, v. 2, n. 3, 2004, p. 3-12.

HERNÁNDEZ HUERTA, José Luis. Freinet en España (1926-1939): escuela popular, historia y pedagogía. Valladolid: Castilla, 2012.

HERNÁNDEZ HUERTA, José Luis; GONZÁLEZ GÓMEZ, Sara. Opinión pública y educación durante la transición a la democracia en Argentina: primeras consideraciones y guía de fuentes documentales. Educació i història: Revista d'història de l'educació, n. 24, 2014, p. 173-215.

HERNÁNDEZ HUERTA, José Luis; GROVES, Tamar. Resistance through teachers' professional development: the Spanish Freniet movement before and after the Franco Dictatorship. INTERNATIONAL STANDING CONFERENCE FOR HISTORY OF EDUCATION, 35, 2013. Anales ... Riga: Ische, 2013, p. 86.

HERNÁNDEZ HUERTA, José Luis; HERNÁNDEZ DÍAZ, José María. Freinet en España (1926-1939). História da Educação, v. 16, n. 36, 2012, p. 147-161.

HERNÁNDEZ HUERTA, José Luis; ORTEGA GAITE, Sonia. Civic cducation and public opinion in Argentina during the transition to democracy (1982-1983). History of Education \& Children's Literature, v. 10, n. 2, 2015, p. 359-389.

HERNÁNDEZ HUERTA, José Luis; SÁNCHEZ BLANCO, Laura. Ideas, materiales y prácticas Freinet en España durante la II República. Innovación Educativa, n. 23, 2013, p. 75-95.

HUNTINGTON, S. La tercera ola: la democratización a finales del siglo XX. Buenos Aires: Paidós, 1990.

IGELMO ZALDÍVAR, Jon. La Universidad de la Tierra en México: una propuesta de aprendizaje convivencial. In: José Luis HERNÁNDEZ HUERTA, Laura SÁNCHEZ BLANCO and Iván PÉREZ MIRANDA. La infancia ayer y hoy. Salamanca, 2009, p. 285-298.

IGELMO ZALDÍVAR, Jon. Desescolarizar la vida: Ivan Illich y la crítica de las instituciones educativas. Madrid: Enclave de Libros, 2016.

IMBERNÓN, Francisco. Il movimento de cooperazione educativa: la renovación pedagógica en Italia. Barcelona: Laia, 1982.

KARAMANOLAKIS, Vangelis. From the fall of the junta to change: the timid transition of higher education in Greece (1974-1982). Espacio, Tiempo y Educación, v. 2, n. 2, 2015, p. 33-48. 
LÓPEZ MARTíN, Ramón. Una escuela de todos y para todos: las prácticas escolares en la transición democrática. Historia de la Educación. Revista Interuniversitaria, n. 21, 2002, p. 67-80.

MARKARIÁN, Vania. La universidad intervenida: cambios y permanencias de la educación superior uruguaya durante la última dictadura (1973-1984). Cuadernos Chilenos de Historia de la Educación, n. 4, 2015, p. 121-152.

MARTíN GONZÁLEZ, María. Enrique de Castro, el cura de los pobres de Madrid. Foro de Educación, v. 2, n. 4, 2004, p. 57-63.

MARTÍN GONZÁLEZ, María. Caminos a la comprensión: entrevista a Enrique de Castro. Foro de Educación, v. 4, n. 7-8, 2006, p. 47-72.

MAYORDOMO PÉREZ, Alejandro. La transición a la democracia: educación y desarrollo político. Historia de la Educación. Revista Interuniversitaria, n. 21, 2002, p. 19-47.

MAYORDOMO PÉREZ, Alejandro. Democràcia i política educativa espanyola, 1975-1985. Educació i història: Revista d'història de l'educació, n. 18, 2011, p. 107-136.

MCEP. Escuela pública. Colaboración, n. 8, 1977, p. 4-7.

MCEP. Algunos aspectos de las prácticas educativas de la Pedagogía Freinet. Colaboración, n. 14, 1978a, p. 3-16.

MCEP. El pacto de la moncloa y sus repercusiones en la política de subvenciones y en la polémica de libertad de enseñanza. Colaboración, n. 10, 1978b, p. 4-5.

MCEP GRUPO TERRITORIAL DE GRANADA. Técnicas Freinet en España. Cuadernos de Pedagogía, n. 35, 1977, p. 8-12.

MCEP GRUPO TERRITORIAL DE MADRID. La participación con los padres. Colaboración, n. 18, 1979, p. 6-7.

MOTA, Luís; FERREIRA, António Gomes. La construcción de una educación democrática: las escuelas de magisterio primario en tiempos de crisis revolucionaria (1974-1976). Espacio, Tiempo y Educación, v. 2, n. 2, 2015, p. 265-288.

NAVARRO, Manuel. Por una escuela pública y popular, ahora. Colaboración, n. 36, 1982, p. 3.

PEREIRA, Miguel. La vuelta a la escuela. Colaboración, n. 12, 1978, p. 3.

POZO ANDRÉS, María del Mar del; BRASTER, Sjaak. The reinvention of the new education movement in the Franco dictatorship (Spain, 1936-1976). Paedagogica Historica, 42, n. 1, 2006, p. 109-126.

POZO ANDRÉS, María del Mar del; BRASTER, Sjaak. El movimiento de la escuela nueva en la España franquista (España, 1936-1976): repudio, reconstrucción y recuerdo. Revista Brasileira de História da Educação, v. 12, n. 3, 2012, p. 15-44.

PUELLES BENÍTEZ, Manuel. El pacto escolar constituyente: génesis, significación y situación actual. Historia de la Educación. Revista Interuniversitaria, n. 21, 2002, p. 49-62.

QUINTERO, Manuel. Correspondencia de nuestros lectores: ¿comienza un nuevo curso? Colaboración, n. 12, 1978, p. 38-39. 
ROCHA, Helenice. A ditadura militar (1964-1985) nas narrativas didáticas brasileiras. Espacio, Tiempo y Educación, v. 2, n. 1, 2015, p. 97-120.

RODRÍGUEZ, Laura Graciela. Funcionarios y políticas educativas en Argentina (1976-1983). Cuadernos Chilenos de Historia de la Educación, n. 4, 2015, p. 62-85.

RODRÍGUEZ TEJADA, Sergio. The anti-Franco student movement's contribution to the return of democracy in Spain. Espacio, Tiempo y Educación, v. 2, n. 2, 2015, p. 77-106.

RUBIO-MAYORAL, Juan-Luis. Sobre los modelos de universidad en la política educativa de la Transición española: herencia y génesis de sus bases (1976-1982). Espacio, Tiempo y Educación, v. 2, n. 2, 2015, p. 125-153.

SOLER, Lorena; ELÍAS, Rodolfo; PORTILLO, Ana. El régimen stronista y su incidencia en la configuración y las prácticas escolares (1954-1970). Cuadernos Chilenos de Historia de la Educación, n. 4, 2015, p. 10-33.

TAPIA, Emiliano; MARTíN GONZÁLEZ, María. Emiliano Tapia, el cura de Buenos Aires (Salamanca). Foro de Educación, v. 2, n. 3, 2004, p. 37-42.

TORGAL, Luís Reis. A universidade em Portugal em período de transição para a democracia e para o neoliberalismo. Espacio, Tiempo y Educación, v. 2, n. 2, 2015, p. 155-171.

TORO BLANCO, Pablo. Tiempos tristes: notas sobre movimiento estudiantil, comunidad y emociones en la Universidad de Chile ante la dictadura de Pinochet (1974-1986). Espacio, Tiempo y Educación, v. 2, n. 2, 2015, p. 107-124.

VASCONCELOS FERNANDES, Luan Aiuá. A repressão contra os professores nas universidades latino-americanas durante a ditadura: os casos da UFMG (1964-1969) e da UTE (1973-1981). Cuadernos Chilenos de Historia de la Educación, n. 4, 2015, p. 86-120.

VV.AA. Conclusiones de las I Jornadas Pedagógicas de Asturias. Cuadernos de Pedagogía, n. 35, 1977a, p. s/p.

VV.AA. Manifiesto de la escuela de verano de Aragón - 77. EVA. Cuadernos de Pedagogía, n. 35, 1977b, p. s/p.

VV.AA. Carta de Mollet (Barcelona). In: MCEP. La escuela moderna en España: movimiento cooperativo de escuela popular. Bilbao, 1979, p. 100-102.

ZURRIAGA, Ferran. El movimiento Freinet en España: itinerario de la escuela moderna. Cuadernos de Pedagogía, n. 54, 1979a, p. 20-22.

ZURRIAGA, Ferran. Itinerario de la escuela moderna. Cuadernos de Pedagogía, n. 54, 1979b, p. 20-22.

ZURRIAGA, Ferran. La segunda época de la experiencia Freinet en España. In: MCEP. La escuela moderna en España: movimiento cooperativo de escuela popular. Bilbao, 1979c, p. $76-112$. 
JOSÉ LUIS HERNÁNDEZ HUERTA é Ph.D. in Education from the University of Salamanca, Spain. Professor at the Faculty of Education (Palencia) of the University of Valladolid, Spain. Lines specially cultivated research are focused on History of Education, highlighting the influence of Celestin Freinet in Spain and representations of education in the collective imaginary of Argentina, Italy and Spain. Editor of the journals Foro de Educación and Espacio, Tiempo y Educación.

Dirección: Facultad de Educación de Palencia - Av. Madrid, 44 - 34004 - Palencia Spain.

E-mail: jlhhuerta@mac.com.

ALBA MARÍA GÓMEZ SÁNCHEZ é researcher at the University of Salamanca, Spain. Dirección: Facultad de Educación. Universidad de Salamanca - Paseo de Canalejas, 169 - 37007 - Salamanca - Spain.

E-mail: albamaria gomez@icloud.com.

Recebido em 29 de janeiro de 2016.

Aceito em 2 de abril de 2016. 